\title{
PERAN KEPALA MADRASAH WANITA DALAM PENGELOLAAN PENERIMAAN SISWA BARU DI MI MAARIF BRAJAN BANJARARUM KALIBAWANG KULON PROGO ${ }^{1}$
}

\author{
Ahmad Salim, \\ (Dosen PAI Sekolah Tinggi Ilmu Agama Alma Ata Yogyakarta)
}

\begin{abstract}
Among the principal's role is to manage the educational institution in getting the number of new students in accordance with the standards that have been done, so it can run educational prosess normally. This study was conducted to find out the role of Principle MI Maarif Brajan Banjar Arum Kalibawang Kulon Progo in getting new students. This study becomes very important due to the Principle MI Maarif is a woman who has a limited step compared with men, but since her leadership the number of new students was increasing. The results showed that the priciple MI Maarif may act as a manager, leader and supervisor and therefore contributes to the satisfaction of internal and external environment prospective student input. Some supporting factors such as the qualification and competence of the Principle MI Maarif Brajan are qualified and religius societie's sect is same as MI Maarif Brajan Banjararum Kalibawang Kulon Progo.
\end{abstract}

Keyword: woman principle's role, management new students

\section{A. Pendahuluan}

Kepala Madrasah merupakan faktor penting dalam menentukan keberlanjutan institusi yang dipimpinnya. Maju mundurnya madrasah sangat ditentukan keberadaan dan peran yang dimainkan kepala madrasah dalam mengelola sumber daya madrasah secara optimal, baik sumber daya berupa manusia ataupun berupa barang. Sumber daya tersebut dalam kaca mata Ibrahim Bafadal dimasukkan dalam komponen pendidikan yang

${ }^{1}$ Artikel ini merupakan hasil resume dari penelitian individu Ahmad Salim di MI Maarif Brajan Banjararum Kalibawang Kulon Progo Yogyakarta, tahun 2011. 
meliputi beberapa unsur yaitu; kurikulum, guru, pegawai administrasi, siswa, sarana prasarana, keuangan dan hubungan kemasyarakatan. ${ }^{2}$

Pemimpin dalam hal ini, adalah kepala madrasah harus bisa berperan sebagai seorang yang dapat mempengaruhi, mengkoordinir, membimbing dan menggerakkan serta memberi contoh orang lain terkait dengan pengembangan ilmu pendidikan dan pembelajaran agar aktivitas yang berhubungan dengan pembelajaran dapat berjalan sesuai yang direncanakan.3 Orang lain yang dimaksud adalah komponen yang ada dalam madrasah, komponen madrasah tersebut harus dapat dikelola secara efektif dan efesien, sehingga dihasilkan kepuasan pelanggan dalam hal ini adalah kepuasaan masyarakat yang anaknya menjadi peserta didik di madrasah yang bersangkutan serta masyarakat umum lainya.

Peran kepala madrasah dalam mengelola siswa atau peserta didik adalah kegiatan yang terkait dengan pencatatan siswa dari proses penerimaan siswa hingga siswa tersebut keluar dari lembaga bersangkutan karena sebab siswa tersebut telah lulus ataupun sebab lain. 4 Lebih jauh, terkait dengan penerimaan siswa tidak hanya terbatas pada mencatat siswa yang telah didapatkan, tetapi peran yang paling urgent adalah justru pada pengelolaan untuk mendapatkan siswa/ peserta didik baru sesuai dengan daya tampung yang ada di madrasah yang bersangkutan. Guna melaksanakan peran sebagaimana disebutkan di atas, maka kepala madrasah harus mempunyai beberapa kompetensi yang memadai serta etos kerja yang tinggi, sehingga dapat mendapatkan siswa sesuai target.

Kepala madrasah bertugas tidak hanya mendapatkan siswa baru sesuai dengan jumlah memadai, tetapi lebih jauh untuk menjaga keberadaan siswa yang telah diperolehnya memperoleh hak-haknya sebagai seorang pembelajar. Peserta didik harus dapat dikembangkan pengetahuan, ketrampilan dan nilai yang dimilikinya sehingga menjadi manusia yang mempunyai kompetensi memadai untuk melanjutkan ke jenjang pendidikan selanjutnya.

${ }^{2}$ Ibrahim Bafadal, Dasar-dasar Manajemen dan Supervisi Taman KanakKanak (Malang, FIP Universitas Negeri Malang; 2000) hlm 6

${ }^{3}$ Hendyat Soetopo dan Wasty Soemanto, Pengantar Operasional Administrasi Pendidikan (Surabaya, Usaha Nasional;1982).hlm 271

${ }^{4}$ Hartati Sukirman, Administrasi dan Supervisi Pendidikan (Yogyakarta, FIP UNY;2000) hlm 17 
Kompetensi dan etos kerja kepala madrasah harus dapat ditunjukkan pada peranya dalam merencanakan, mendistribusikan beban kerja serta mengontrol kerja guru dan tim dalam mendapatkan siswa baru. Aktivitas kepemimpinan adalah aktivitas mempengaruhi kelompok atau anggota, sehingga mereka bisa melaksanakan kerja sesuai yang diharapkan.5 Kompetensi yang dimiliki oleh kepala madrasah sebagai seorang leader di institusinya tersebut tidak akan berperan banyak jika tidak didistribusikan secara benar, sehingga komponen pendidikan yang ada dapat terkelola dengan baik. Kerjasama dalam menghidupkan roda organisasi madrasah harus dikelola oleh kepala madrasah dengan memperhatikan konsep "the right man on the right place". Konsep ini akan mendorong stakeholder madrasah bekerja bahu membahu dalam mengerjakan suatu program kegiatan yang dilaksanakan termasuk juga dalam hal penerimaan siswa baru.

Madrasah Ibtidaiyah Maarif Brajan (MI Maarif Brajan) yang berlokasi di desa Banjaarum Kalibawang Kulon Progo Daerah Istimewa Yogyakarta merupakan MI swasta di bawah lembaga pendidikan Maarif NU Kabupaten Kulon Progo. Madrasah ini, mulai tahun 2009 yang lalu dipimpin oleh kepala madrasah wanita, dimana sebelumnya belum pernah seorang wanita memimpin madrasah ini. Namun demikian walaupun kepala madrasah di MI Maarif ini adalah seorang wanita tetapi peserta didik barunya justru mengalami peningkatan semenjak beliau diangkat menjadi kepala madrasah tiga tahun terakhir ini.

Penerimaan siswa baru di lembaga pendidikan swasta seperti MI Maarif Brajan merupakan agenda tahunan yang sangat penting dan menentukan keberadaan MI di tahun mendatang. Siswa sebagai sumber utama "pendapatan" madrasah harus dapat dikelola sehingga eksistensi madrasah dapat terjaga dan berkompetisi dengan lembaga lain. Kebanyakan sekolah swasta atau madrasah mendapatkan siswa dari siswa yang tidak diterima oleh sekolah/madrasah negeri, kecuali beberapa alasan tertentu seperti kualitas, jangkauan siswa dengan keberadaan sekolah/madrasah yang ada, serta kesamaan keyakinan agama tertentu.

Keadaan di atas menarik peneliti untuk mengungkap peran kepala madrasah wanita dalam mengelola penerimaan siswa baru sehingga ada peningkatan jumlah siswa baru. Penelitian ini menjadi penting untuk

${ }^{5}$ Hadari Nawawi, Administrasi Pendidikan (Jakarta, PT. Gunung Agung; 1987) hlm 78 
dilakukan mengingat MI Maarif adalah madrasah swasta yang sangat membutuhkan kehadiran jumlah siswa yang cukup memadai, tetapi di lain pihak justru kepala yang memimpin madrasah ini adalah seorang wanita yang secara kodrat memiliki keterbatasan untuk jauh melangkah dibandingkan dengan seorang laki-laki. Padahal selama ini jumlah siswa di MI Maarif Brajan ini jauh dikatakan memadahi.

\section{B. Peran dan Tugas Kepala Madrasah Ibtidaiyah}

Sebagai seorang pemimpin institusi pendidikan, kepala madrasah mempunyai berbagai macam peran yang harus dimainkan guna mencapai tujuan madrasah yang telah ditetapkanya. Kepala madrasah yang berhasil adalah apabila mereka memahami keberadaan madrasah sebagai organisasi yang kompleks, serta mampu melaksanakan peranan kepala madrasah sebagai seorang yang diberi tanggungjawab untuk memimpin madrasah. Kepemimpinan kepala madrasah mencerminkan tanggung jawab untuk menggerakkan seluruh sumber daya yang ada di madrasah, sehingga lahir etos kerja dan produktivitas yang tinggi dalam mencapai tujuan.

Ada beberapa peran yang harus ada di diri kepala madrasah termasuk juga madrasah ibtidaiyah yaitu peran kepala madrasah sebagai (1) educator (pendidik); (2) manajer; (3) administrator; (4) supervisor (penyelia); (5) leader (pemimpin); (6) pencipta iklim kerja; dan (7) wirausahawan.

a. Sebagai educator, kepala madrasah harus memahami kompetensi guru agar guru yang bersangkutan bisa meningkatkan kualitas pembelajaranya. Menurut Mulyasa (2005) sebagai seorang educator kepala madrasah harus menekankan beberapa hal yaitu diantaranya meliputi; pembinaan terhadap mental, pembinaan terhadap moral, pembinaan terhadap sarana fisik serta pembinaan terkait dengan artistic. ${ }^{6}$

b. Sebagai Manajer, kepala madrasah mempunyai fungsi sebagai pengatur atau pengelola institusinya. Guna melaksanakan perannya sebagai seorang manajer kepala madrasah harus memiliki strategi yang efektif untuk melibatkan, mengkomando, memberi tauladan kepada bawahanya yaitu tenaga pendidik dan tenaga kependidikan dalam kerjasama kooperatif, sehingga kualitas pembelajaran dapat dicapai dan ditingkatkan. Kepala

${ }^{6}$ Mulyasa, Menjadi Kepala Sekolah Profesional (Bandung; Remaja Rosdakarya, 2005) hlm 99 
madrasah harus mempunyai kepekaan manajerial, agar bisa menempatkan guru dan karyawan dalam irama kerja yang sesuai dengan kualifikasi dan kompetensinya. Menurut Stoner dalam Mulyasa (2005) ada beberapa fungsi manajer dalam institusi pendidikan yaitu; bekerja dengan dan melalui orang lain, bertanggungjawab dan mempertanggungjawabkan, mampu menghadapi persoalan, berpikir realistik dan konseptual, sebagai juru penengah, sebagai seorang politisi, sebagai diplomat, pengambil kebijakan.

c. Sebagai Administrator, kepala madrasah bertanggungjawab penuh terhadap kelancaran pelaksanaan pendidikan dan pengajaran di institusi dia bekerja. Guna melaksanakan tugasnya secara optimal maka kepala madrasah harus memahami, menguasai, dan mampu melaksanakan kegiatan-kegiatan terkait dengan administrasi pendidikan.7 Masih menurut Ngalim Purwanto bahwa untuk melaksanakan perannya sebagai administrator maka kepala madrasah harus membuat beberapa langkah yaitu; membuat perencanaan madrasah, menyusun organisasi madrasah, bertindak sebagai koordinator dan pengarah, serta melaksanakan pengelolaan kepegawaian.

d. Sebagai Supervisor, kepala madrasah berperan banyak terkait dengan pembinaan secara terstruktur agar guru dan pegawai lain dapat melaksanakan pekerjaanya secara efektif. Fungsi kepala madrasah pada bidang ini tidak hanya sebagai kontrol atas kinerja bawahanya berdasarkan kriteria standar yang telah ditentukan sebulumnya, tetapi lebih sebagai aktivitas menentukan kondisi yang esensial yang akan menjamin tercapainya tujuan-tujuan pendidikan. Menurut Ngalim Purwanto beberapa usaha kepala madrasah yang dapat dilakukan sebagai seorang supervisor yaitu; membangkitkan dan merangsang guru untuk melaksanakan tugasnya secara optimal, bersama guru berusaha mencari dan menemukan serta mengembangkan metode, strategi, serta media pembelajaran yang sesuai dengan perkembangan kurikulum, membina kerjasama yang baik antara guru dan pegawai lainya, meningkatkan kualitas pembelajaran guru. ${ }^{8}$

${ }^{7}$ Ngalim Purwanto, Administrasi dan Supervisi Pendidikan (Bandung; Remaja Rosdakarya, 2005) hlm 106

${ }^{8}$ Ibid 
e. Kepala sebagai seorang Leader, Kepala madrasah sebagai pemimpin atau leader berperan sebagai pengendali dari madrasah yang dipimpinya, oleh karena itu kepala madrasah harus memiliki kualifikasi dapat dipercaya dapat dipercaya, jujur, dan tanggungjawab, memahami guru, karyawan, dan siswa, memiliki visi dan memahami misi madrasah, mengambil keputusan urusan intern dan ekstern madrasah, membuat, mencari, dan memiliki gagasan baru. 9

f. Kepala madrasah sebagai Inovator

Kepala madrasah sebagai innovator mempunyai tugas sebagai berikut: melakukan pembaharuan di bidang KBM, BK, Ekstrakurikuler.

g. Kepala madrasah sebagai Motivator

Kepala madrasah sebagai motivator mempunyai tugas sebagai berikut:

1. Mengatur ruang kantor yang konduktif untuk bekerja.

2. Mengatur ruang kantor yang konduktif untuk KBM dan BK.

3. Mengatur ruang laboratorium yang konduktif untuk praktikum.

4. Mengatur ruang perpustakaan yang konduktif untuk praktikum.

5. Mengatur halaman atau lingkungan madrasah yang sejuk dan teratur.

h. Menciptakan hubungan kerja yang harmonis sesama guru dan karyawan.

i. Menciptakan hubungan kerja yang harmonis antar madrasah dan lingkungan. ${ }^{10}$

Kaitanya dengan peran kepala madrasah sebagaimana dipaparkan di atas dan jika mengacu pada Peraturan Menteri Pendidikan Nasional Republik Indonesia Nomor 13 Tahun 2007 tentang Standar Kepala

\section{${ }^{9}$ Ibid}

${ }^{10} \mathrm{Ibid}$, lihat juga Permen Pendidikan Nasional No. 28 Tahun 2010 Tentang Penugasan Guru Sebagai Kepala Sekolah/Madrasah. 
Sekolah/Madrasah, maka kepala sekolah juga harus berjiwa wirausaha. Maka kepala madrasah mempunyai peran yang semakin berat guna membuat madrasah lebih berdaya termasuk juga agar madrasah mempunyai penghasilan tidak hanya tergantung dari jumlah siswa saja.

\section{Standar Kualifikasi dan Kompetensi Kepala Madrasah Ibtidaiyah}

Untuk menjadi kepala madarasah maka seorang harus menjadi guru, sebab sarat utama kepala madrasah adalah telah menjadi guru, karena sebenarnya kepala sekolah adalah jabatan yang disandang oleh guru manakala memiliki kualifikasi tertentu. Adapun standar kualifikasi kepala madrasah menurut Peraturan Menteri Pendidikan Nasional No 13 tahun 2007 Tentang standar Kepala Sekolah/Madrasah dapat dikelompokkan menjadi standar umum dan khusus. Standar umum yaitu Kualifikasi kepala madrasah terkait dengan:

a. Memiliki kualifikasi akedemik sarjana atau diploma 4 dari perguruan tinggi yang terakreditasi

b. Pada waktu diangkat menjadi kepala madrasah berumur paling tinggi 56 tahun

c. Memiliki pengalaman mengajar sebagai guru minimal 5 tahun pada jenjang madrasah masing-masing

d. Memiliki pangkat paling rendah III/C pagi PNS dan bagi pegawai swasta disetarakan oleh lembaga yang berwenang atau yayasan.

Terkait dengan kualifikasi khusus yaitu syarat yang terkait langsung yang berhubungan dengan tingkat atau level lembaga pendidikan yang akan dia pimpin. Adapun mengenai kualifikasi terkait dengan kepala MI adalah sebagai berikut:

a. Berstatus sebagai guru MI

b. Memiliki sertifikat pendidik sebagi guru MI

c. Memiliki sertifikat Kepala Madrasah yang diterbitkan oleh lembaga pemerintah.

Melihat kualifikasi standar kepala madrasah sebagaimana diterangkan dalam Peraturan Menteri Pendidikan Nasional di atas maka jelas bahwa kepala madrasah adalah guru madrasah yang telah mengabdikan diri selama periode tertentu dan dianggap memiliki kualifikasi untuk memimpin madrasah yang bersangkutan. Ini menandakan 
bahwa untuk menjadi kepala sekolah / madarasah harus berkarir menjadi guru dulu, sebab kepala madrasah akan memimpin para guru di tempat ia bekerja.

Berhubungan dengan kompetensi kepala madrasah adalah sebuah kemampuan melekat di diri seseorang yang harus ada jika seseorang akan melaksanakan perannya sebagai kepala madrasah. Beberapa kompetensi yang harus dimiliki oleh kepala madrasah menurut Peraturan Menteri Pendidikan Nasional No 13 tahun 2007 Tentang standar Kepala Sekolah/Madrasah adalah sebagai berikut;

1. Kompetensi kepribadian

Kompotensi terkait dengan pengendalian dirinya sebagai seorang pemimpin seperti berakhlak mulia, memiliki integritas dan kepribadian sebagai seorang pemimpin, keinginan yang kuat dalam mengembangkan diri, sikap terbuka dalam melaksanakan tugas pokok dan program, memiliki bakat dan minat sebagai pemimpin pendidikan.

2. Kompetensi manajerial

Kompotensi terkait dengan perencanaan sekolah, mengembangkan organisasi sekolah/madrasah, memimpin madrasah dalam rangka pendayagunaan sumber madrasah, mengelola madrasah menuju pembelajaran yang efektif, menciptkan budaya organisasi yang kondusif, mengelola sarana prasarana, membangun humas, mengelola peserta didik dalam rangka penerimaan peserta didik baru dan penempatan serta pengembangan kapasitas peserta didik, mengelola dan mengembangkan kurikulum, mengelola keuangan madrasah, mengelola tata usaha madrasah, mengelola unit madrasah, mengelola system informasi manajemen madrasah, memanfaatkan iptek, mengevaluasi semua program yang telah dilaksanakan dan cara tindak lanjutnya.

3. Kompetensi kewirausahaan

Kompetensi terkait dengan penciptaan inovasi yang berguna bagi madrasah, kerja keras untuk kemajuan madrasah, memiliki motivasi yang kuat untuk sukses dalam melaksanakan tugas pokok sebagai pemimpin madrasah, pantang menyerah dalam dan selalu mencari solusi terbaik guna menghadapi problem yang dihadapi oleh madrasah, memiliki jiwa wirausaha dalam mengelola kegiatan program jasa madrasah sebagai sumber belajar peserta didik. 
4. Kompetensi Supervisi

Kompetensi yang terkait dengan merencanakan program supervisi akademik dalam rangka peningkatan profesionalisme guru, melaksanakan supervisi akademik dengan menggunakan teknik supervise yang tepat, menindaklanjuti supervisi yang dilakukan dalam rangka peningkatan profesionalisme guru.

5. Kompetensi Sosial

Kompetensi yang terkait dengan kemampuan bekerjasama dengan pihak lain untuk kemajuan madrasah, berpartisipasi dalam kegiatan social kemasyarakatan, memiliki kepekaan social terhadap seseorang atau kelompok.

Dari beberapa kompetensi yang dipersyaratkan oleh peraturan menteri pendidikan nasional di atas maka dapat dilihat bahwa kompetensi atau kemampuan yang terkait langsung dengan pengelolaan penerimaan siswa baru adalah kompetensi kepala madrasah sebagai seorang manajer atau kompetensi manajerial. Namun demikian kepala madrasah tidak mungkin bisa melaksanakan kompetensi ini secara terpisah, kompetensi satu dengan lainya saling berhubungan, saling melengkapi dan dapat dilaksanakan secara bersama-sama.

Kepala madrasah harus dapat memberdayakan komponen yang ada di madrasah secara optimal sehingga tujuan program kegiatan dapat tercapai sesuai harapan. Made Pidarta (1988) mengatakan bahwa seorang pemimpin pendidikan harus memiliki minimal tiga kompetensi untuk melaksanakan kepemimpinannya secara optimal yaitu, keterampilan konseptual; ketrampilan untuk bisa memahami dan menggerakkan organisasi, kemudian keterampilan manusiawi yaitu keterampilan untuk memotivasi, kerjasama dan memimpin sedangkan yang terakhir yaitu kemampuan atau keterampilan teknik yaitu keterampilan terkait dengan menggunakan teknik, metode, pengetahuan guna menyelesaikan tugas tertentu yang dibebankan kepadanya.

Lebih lanjut Mulyasa (2002) mengemukakan bahwa pemimipin pendidikan yang efektif harus memiliki beberapa kriteria yaitu:

1. Mampu memberdayakan guru untuk melaksanakan pembelajaran dengan baik

${ }^{11}$ Made Pidarta, Manajemen Pendidikan Indonesia (Jakarta, Bumi Aksara;1988) hlm 77 
2. Mampu menyelesaikan pekerjaan sesuai dengan target waktu yang tepat

3. Mampu menjaga hubungan yang harmonis dengan masyarakat lain madrasah

4. Mampu menerapkan konsep kepemimpinan sesuai dengan tingkat maturity guru

5. Mampu bekerja dengan tim manajemen

6. Mampu bekerja mewujudkan tujuan madrasah secara produktif sesuai tujuan yang telah ditetapkan sebelumnya. ${ }^{12}$

Senada dengan Mulyasa di atas Nanang Fatah (1996) mengemukakan bahwa efektifitas kepemimpinan kepala madrasah tidak hanya dipengaruhi oleh kompetensi dari kepala madrasah saja, faktor lain juga sangat mempengaruhi. Nanang Fatah mengemukakan bahwa ada beberapa faktor yang membuat kepemimpinan yang dilakukan oleh pemimpin pendidikan ini dapat berjalan dengan sukses yaitu; terkait dengan kepribadian kepala madrasah, pengharapan dan perilaku atasan, karakteristik, kebutuhan tugas, iklim dan kebijakan organisasi, harapan dan perilaku rekan kerja. ${ }^{13}$ Kepribadian menurutnya sangat terkait dengan pengalaman masa lalu dan harapan pemimpin yang terdiri dari nilai-nilai, latar belakang kehidupan kepala madrasah akan sangat mempengaruhi gaya atau style dari kepemimpinan yang diterapkan oleh kepala madrasah.

\section{Kendala yang dihadapi oleh Kepala Madrasah Ibtidaiyah}

Madrasah Ibtidaiyah adalah sekolah dibawah kementrian Agama pada tingkat dasar mempunyai beberapa problem yang hampir sama dengan madrasah secara umum. Kondisi madrasah pasca dikeluarkannya SKB tiga menteri (Menteri Agama, Menteri Pendidikan dan Kebudayaan, dan Menteri dalam Negeri) berimbas pada pengurangan beberapa materi agama untuk diganti dengan materi umum sehingga berpengaruh kepada eksistensi madrasah yang sudah cukup kuat beriringan dengan sekolah umum. Usaha tersebut di atas, mengakibatkan eksisensi madrasah mendapatkan pengakuan yang sama dengan sekolah pada pelbagai segi termasuk juga pada izajah yang diperolehnya oleh siswa madrasah.

2002) hlm126

${ }^{12}$ Mulyasa, Manajemen Berbasis Sekolah (Bandung, Remaja Roda Karya;

${ }^{13}$ Nanang Fatah, Landasan Manajemen Pendidikan ( Bandung, Remaja Rosda Karya;1996) hlm 99-100 
Kesejajaran madrasah dengan sekolah umum ternyata kemudian menimbulkan masalah sendiri bagi madrasah. Beberapa masalah yag dihadapi madrasah secara umum menurut Raharjo (2009) adalah antara lain: berkurangnya muatan materi pendidikan agama, sehingga mengakibatkan pendangkalan pemahaman agama bagi siswa madrasah. Muatan kurikulum agama sebelum SKB dirasa belum mampu mencetak muslim sejati, apalagi kemudian dikurangi. Tamatan Madrasah juga dirasakan mempunyai kompetensi serba tanggung. Pengetahuan agamanya tidak mendalam sedangkan pengetahuan umumnya juga rendah.14

Problem di atas selain akibat dari pengurangan mata pelajaran agama di madrasah juga karena beberapa hal yaitu dualisme kebijakan pemerintah antara sekolah dan madrasah (terutama pra-reformasi), lemahnya sistem manajemen madrasah dan rendahnya kualitas SDM baik guru ataupun tenaga kependidikan serta rendahnya kualitas raw input madrasah. Akibat dari berbagai persoalan di atas pada giliranya memunculkan efek domino bagi madrasah salah satunya adalah madrasah secara umum masih dianggap sekolah kelas dua setelah sekolah umum milik diknas.

Keberadaan madrasah yang sebagian besar dikelola oleh swasta juga menjadi permasalahan tersendiri bagi kepala madrasah dan stakeholder madrasah, sebab secara financial guna melaksanakan semua aktivitas madrasah sebagian besar mendanainya secara mandiri dan sangat tergantung dari jumlah siswa yang ada di madrasah. Menurut Husni Rahim keadaan tersebut justru menjadi keunikan tersendiri bagi lembaga pendidikan, tetapi secara financial kenyataan di lapangan masih jarang madrasah milik swasta yang bisa berkompetisi dengan madrasah milik pemeintah terutama dalam hal kuantitas siswa yang dimilikinya. Husni Rahim menyatakan bahwa madrasah milik swasta adalah $92.5 \%$ lainya adalah milik negeri.15

Keberadaan madrasah terutama MI yang sebagian besar terletak di pinggiran atau di desa juga menjadi kendala bagi kepala madrasah untuk

\footnotetext{
${ }^{14}$ Raharjo, Madrasah Sebagai Centre of Excellent, Makalah Seminar IAIN Wali Songo Semarang (Semarang, 2009) hlm 23

${ }^{15}$ Husni Rahim, Arah Baru Pendidikan Islam di Indonesia, (Jakarta, Logos;2001) hlm 131
} 
memimpin institusi yang dipimpinnya. ${ }^{16}$ Masyarakat pinggiran atau pedesaan dengan tingkat social ekonomi, pendidikan dan jumlah penduduk yang belum tinggi di banding masyarakat perkotaan akan menjadi kendala tersendiri bagi kepala madrasah untuk mengembangkan madrasah dibanding lembaga pendidikan yang berlokasi di perkotaan. Kepala madrasah akan kesulitan untuk menaikkan SPP untuk siswa karena sebagian besar orang tua siswa berpenghasilan rendah. Kepala madrasah juga akan mengalami kesulitan untuk meningkatkan jumlah siswa madrasah, karena memang jumlah penduduk di desa atau masyarakat pinggiran jauh lebih sedikit dibanding dengan di daerah perkotaan.

Muhaimin (2011) mengemukakan lebih jauh tentang pentingnya pemasaran lembaga pendidikan termasuk juga madrasah. Diantara faktor yang sangat mempengaruhi daya tarik orang tua calon siswa untuk menyekolahkan anaknya ke sekolah atau madrasah adalah lokasi atau letak madrasah yang mudah dicapai oleh kendaraan umum. ${ }^{17}$

\section{E. Pengelolaan Penerimaan Siswa Baru}

Penerimaan siswa baru menjadi agenda penting bagi semua lembaga pendidikan termasuk juga pada madrasah. Penerimaan siswa baru dapat berjalan dengan efektif jika ada campur tangan yang kuat dan dan professional oleh pemimpin madrasah yaitu kepala madrasah. Pengelolaan penerimaan siswa baru mestinya berdasarkan pada daya tampung yang ada pada madrasah yang bersangkutan.

Ibrahim Bafadal mengemukakan ada beberapa hal yang biasa dilakukan dalam peneriamaan siswa baru yaitu;

1. Persiapan yang meliputi; pembentukan panitia, pengkajian beberapa aturan terkait penerimaan siswa baru, penetapan persyaratan untuk masuk madrasah, penetapan prosedur, penetapan jadwal, penyiapan fasilitas.

2. Penyebaran informasi penerimaan siswa baru; bisa dilakukan di media cetak atau elektronik

${ }^{16}$ Murif Yahya, Eksistensi Madrasah Menghadapi Globalisasi (Bandung, Jurnal Media Pendidikan.Vol XIV No I. April $2009: 1-100$ )

${ }^{17}$ Muhaimin, Manajemen Pendidikan, Aplikasinya dalam Penyusunan Rencana Pengembangan Sekolah/madrasah, (Jakarta, Kencana Prenada Media Group;2011) hlm 110 
3. Pelaksanaan pendaftran siswa baru; melayani pendatar, mengecek semua isian formulir, merekap pendaftar.

4. Seleksi

5. Pengumuman hasil seleksi

6. Herregistrasi ${ }^{18}$

Terkait dengan penerimaan siswa baru menurut Muhaimin,dkk (2009) mestinya harus dilakukan dengan pengelolaan yang sistematis guna mempromosikan visi, misi madrasah berdasarkan kebutuhan nyata baik itu untuk stakeholder atau pun masyarakat social pada umumnya. Lebih jauh dia mengatakan bahwa meskipun madrasah adalah lembaga nirlaba, tetapi terkait dengan promosi ke publik harus dilakukan dengan prinsif manajemen professional. Promosi seperti ini sangat lazim dilakukan oleh perusahaan profit. Pemasaran di lembaga pendidikan termasuk madrasah berfungsi untuk membentuk citra baik terhadap lembaga dan menarik minat sejumlah calon siswa ${ }^{19}$

\section{F. Dampak Peran Kepala Madrasah dalam Mengelola Penerimaan Siswa Baru}

Dampak dari usaha yang dilakukan oleh Kepala MI Maarif Brajan adalah dari sisi kuantitas siswa baru madrasah mengalami peningkatan, meskipun dari sisi daya tampung jumlah tersebut belum memenuhi target yang ada. Dari data yang diperoleh peneliti maka ada peningkatan jumlah siswa baru di MI Maarif Brajan pada tahun 2009, 2010 dan 2011 dibanding tahun sebelumnya. Jumlah siswa baru pada tahun 2009 adalah 11, pada tahun 2010 adalah 11 dan tahun 2011 adalah 12. Jumlah tersebut di atas tentu sangat belum mencapai target daya tampung yang ada, tetapi kecendrungan kenaikan perlu diajukan apresiasi.

Dari sisi kepuasaan masyarakat/orang tua siswa terhadap pelayanan kepada calon siswa baru ditemukan kepuasaan dari orang tua siswa. Pelayanan dengan cara jemput bola terutama di RA Masyithoh Brajan, memberikan fasilitas yang diperlukan oleh siswa baru seperti seragam, tas dan buku kepada calon peserta didik. Pelayanan seperti ini akan memberikan efek yang bagus ke depan terhadap kemajuan MI Maarif

\footnotetext{
${ }^{18}$ Ibrahim Bafadal, Dasar-dasar Manajemen dan Supervisi Taman Kanakkanak.........hlm 33-34

${ }^{19}$ Muhaimin, Manajemen Pendidikan, Aplikasinya dalam Penyusunan Rencana Pengembangan Sekolah/madrasah,.............. hlm 99
} 
Brajan. Kerjasama terutama terhadap RA Masyithoh dalam pengumuman dan perekrutan siswa baru jelas mempengaruhi keberadaan MI Maarif Brajan.

Panitia penerimaan siswa baru yang ada di MI Maarif Brajan yang terdiri dari beberapa guru mengalami perlakuan yang memuaskan, mereka merasa diperhatikan dan dibimbing, sehingga kerja mereka dapat berjalan dengan efektif. Iklim organisasi yang terjalin ini jelas akan mempengaruhi kinerja guru dan semua stake holder madrasah. ${ }^{20}$

\section{G.Faktor Pendukung dan Penghambat Pengelolaan Penerimaan Siswa Baru}

Ada beberapa faktor yang mendukung usaha kepala madrasah dalam mengelola penerimaan siswa baru, baik terkait dengan pribadi kepala yang bersangkutan juga terkait dengan MI Maarif Brajan dan lingkungan sekitar MI Maarif Brajan. Faktor yang terkait dengan pribadi yaitu kualifikasi dan kompetensi Kepala MI Maarif Brajan berkualifikasi Sarjana (S1) dari perguruan Tinggi Ilmu Tarbiyah yang telah terakkreditasi yaitu Sekolah Tinggi Ilmu Tarbiyah Muhamadiyah Wates Kulon Progo. Secara kualifikasi kepangkatan Kepala MI Maarif Brajan sudah golongan IVA. 21

Pengangkatan kepala MI Maarif Brajan juga telah memenuhi standar yang benar yaitu berdasarkan SK dari LP Maarif Kulon Progo serta SK dari Mapenda Kemenag Kulon Progo. Pertimbangan untuk mengangkat kepala madrasah yang bersangkutan telah berdasarkan rapat dari pengurus harian LP Maarif Cabang Kulon Progo dengan meminta saran dari komite MI Maarif yang bersangkutan. Dari cara ini sangat jelas bahwa pengangkatan dari kepala MI Maarif Brajan mempunyai dasar legal formal yang kuat.

Secara personal diakui kepala MI Maarif Brajan mempunyai ketekunan dan keteguhan dalam memimpin madrasah. Etos kerja yang tinggi juga ditunjukkan oleh kepala madrasah terbukti dari kedisiplinan kepala MI Maarif Brajan dalam menjalankan tugas. Menurut Harjono salah satu guru senior di MI Maarif Brajan ini bahwa kepala MI Maarif Brajan jarang sekali datang terlambat ke madrasah meskipun jarak rumah dengan

\footnotetext{
${ }^{20}$ Hasil Wawancara dengan guru MI Maarif Brajan 24 Juli 2011

${ }^{21}$ Diambil dari Dokumentasi MI Maarif Brajan 19 Juli 2011
} 
MI juga tidak dekat dan medanya pengunungan yang membutuhkan perjuangan untuk dapat sampai kelokasi bersangkutan. Kepala MI juga mempunyai komunikasi yang baik dengan guru yang dipimpinnya serta masyarakat yang ada di dekat madrasah.

Mempunyai keterikatan dengan lembaga pendidikan Maarif NU. Jelas MI Maarif adalah milik lembaga pendidikan Maarif NU, sementara lembaga pendidikan Maarif NU juga mempunyai lembaga pendidikan tingkat TK/RA. Salah satu RA yang berlokasi dekat dengan MI Maarif Brajan adalah RA Masyithoh Brajan yang berjarak tidak kurang dari 200 M. Hampir semua siswa dari RA Masyitoh Brajan meneruskan ke MI Maarif Brajan, kecuali ada alasan seperti orang tua siswa yang bersangkutan pindah, jarak rumah siswa agak jauh.

Fanatisme terhadap aliran keagamaan masyarakat disekitar MI Maarif Brajan yang sebagian besar berorganisasi Nahdlatul Ulama (NU) juga menjadi faktor pendukung eksistensi MI Maarif Brajan. Banyak orang tua yang menyekolahkan anaknya ke MI Maarif Brajan lebih banyak atas dasar fanatisme ini dibanding pertimbangan lain seperti kualitas/mutu dan lainya. Keadaan ini di satu sisi juga memberikan keuntungan bagi madrasah atau kepala MI Maarif Brajan dalam memanfaatkan factor ini.

Kemudian beberapa faktor yang menghambat terhadap pengelolaan penerimaan siswa baru adalah, letak geografis MI Maarif Brajan yang ada di daerah pengunungan sehingga untuk menempuh medan tersebut sangat berat. Kondisi ekonomi sosial dan kepadatan penduduk yang sanagt rendah mengakibatkan input siswa ke MI Maarif Brajan rendah. Tingkat kompetisi untuk masuk ke jenjang pendidikan dasar di daerah ini ternyata juga cukup tinggi meskipun penduduk di daerah ini tidak besar. Daerah tempat dimana MI Maarif Brajan ini ada 2 sekolah yaitu SD Negeri Ngaran Samigaluh Kulon Progo, MI Muhamadiyah Nogosari Girimulyo. Kedua lembaga pendidikan ini, SD Negeri Ngaran dan MI Muhamadiyah Nogosari memang beda kecamatan dengan MI Maarif Brajan, tetapi secara jarak tidak lebih dari 2 KM antara satu dengan yang lainya.

Keaadaan tersebut jelas sangat menjadi kendala bagi kepala madrasah untuk mengelola penerimaan siswa baru, walaupun masingmasing sekolah/madrasah sudah mempunyai pangsa pasar masing-masing tetapi tetap akan mengurangi input yang masuk di masing-masing sekolah atau madrasah tersebut. 


\section{H. Kesimpulan}

Peran kepala MI maarif dalam mengelola penerimaan siswa baru dapat dilaksanakan secara efektif, baik peranya sebagai manajer, sebagai leader ataupun sebagai supervisor. Walupun peran kepala madrasah tersebut tidak dapat dipisahkan satu sama lainya, tetapi peran tersebut saling terkait satu sama lainya.

Dampak dari usaha kepala MI Maarif dalam mengelola penerimaan siswa baru dapat dilihat dari kecenderungan kenaikan jumlah siswa baru MI Maarif Brajan semenjak tahun 2009 yang lalu hingga penelitian ini dilakukan. Masyarakat merasa puas terhadap pelayanan tim penerimaan siswa baru, terutama pada pemberian seragam dan tas bagi siswa baru yang mendaftar di MI Maarif Brajan.

Faktor pendukung dalam pengelolaan penerimaan siswa baru adalah beberapa hal yang terkait dengan personal kepala MI Maarif Brajan dan juga terkait dengan usaha atau kegiatan yang dilakukan oleh kepala MI Maarif Brajan. Faktor yang terkait dengan personal kepala MI Maarif Brajan adalah; kualifikasi dan kompetensi kepala MI Maarif Brajan memadai. Sedangkan faktor yang ada pada luar kepala MI Maarif Brajan adalah kondisi masyarakat yang berfaham sama dengan MI Maarif NU Brajan. Sedangkan faktor penghambat yaitu kondisi sosial ekonomi penduduk yang banyak berpencaharian petani serta kepadatan penduduk di sekitar MI yang masih rendah. 


\section{DAFTAR PUSTAKA}

Hadari Nawawi, Administrasi Pendidikan, Jakarta, PT. Gunung Agung, 1987. Hartati Sukirman, Administrasi dan Supervisi Pendidikan, Yogyakarta, FIP UNY,2000.

Hendyat Soetopo dan Wasty Soemanto, Pengantar Operasional Administrasi Pendidikan,Surabaya, Usaha Nasional,1982.

Husni Rahim, Arah Baru Pendidikan Islam di Indonesia, Jakarta, Logos,2001. Ibrahim bafadal, Dasar-dasar Manajemen dan Supervisi Taman Kanak-Kanak Malang, FIP Universitas Negeri Malang, 2000.

Made Pidarta, Manajemen Pendidikan Indonesia, Jakarta, Bumi Aksara,1988.

Mulyasa, Manajemen Berbasis Sekolah, Bandung, Remaja Roda Karya, 2002.

Mulyasa, Menjadi Kepala Sekolab Profesional, Bandung; Remaja Rosdakarya, 2005.

Muhaimin, Manajemen Pendidikan, Aplikasinya dalam Penyusunan Rencana Pengembangan Sekolah/madrasah, Jakarta, Kencana Prenada Media Group,2011.

Murif Yahya, Eksistensi Madrasah Menghadapi Globalisasi, Bandung, Jurnal Media Pendidikan.Vol XIV No I. April 2009 :1-100.

Nanang Fatah, Landasan Manajemen Pendidikan, Bandung, Remaja Rosda Karya,1996.

Ngalim Purwanto, Administrasi dan Supervisi Pendidikan, Bandung, Remaja Rosdakarya, 2005.

Peraturan Menteri Pendidikan Nasional No 13 tahun 2007 Tentang standar Kepala Sekolah/Madrasah

Peraturan Menteri Pendidikan Nasional No.28 Tahun 2010 Tentang Penugasan Guru Sebagai Kepala Sekolah/Madrasah.

Raharjo, Madrasab Sebagai Centre of Excellent, Makalah Seminar IAIN Wali Songo Semarang, Semarang, 2009. 


Zukhrufarisma, Peran Kepala Sekolah Profesional,
zukhrufarisma.wordpress.com/2011/03/20/ diakses 4 Mei 2011 